archives-ouvertes

\title{
Residential Mobility
}

Guillaume Le Roux

\section{To cite this version:}

Guillaume Le Roux. Residential Mobility. The Wiley Blackwell Encyclopedia of Urban and Regional Studies, Wiley , pp.1-7, 2019, 9781118568446. 10.1002/9781118568446.eurs0269 . hal-02364270

\section{HAL Id: hal-02364270 \\ https://hal.archives-ouvertes.fr/hal-02364270}

Submitted on 14 Nov 2019

HAL is a multi-disciplinary open access archive for the deposit and dissemination of scientific research documents, whether they are published or not. The documents may come from teaching and research institutions in France or abroad, or from public or private research centers.
L'archive ouverte pluridisciplinaire HAL, est destinée au dépôt et à la diffusion de documents scientifiques de niveau recherche, publiés ou non, émanant des établissements d'enseignement et de recherche français ou étrangers, des laboratoires publics ou privés. 


\title{
Residential Mobility
}

\author{
Guillaume Le Roux
}

Institut National d'Etudes Démographiques, France

\begin{abstract}
Residential mobility has been the subject of much research in various disciplines such as demography, economics, geography, history, and sociology. The meaning of this concept changes depending on the discipline, the date, and the national academic context. In its broadest sense, residential mobility can be defined as residence relocation regardless of the distance between the dwellings. The focus on the topic shifted from the measure of interregional migration to the study of individual behaviors in urban areas. In the meantime, the approaches diversified from a transversal perspective to a life course perspective, offering promising prospects of research.
\end{abstract}

Keywords: housing; migration; residential mobility; spatiotemporal data; urban geography

Residential mobility has been the subject of much research in various disciplines such as demography, economics, geography, history, and sociology. The meaning of the concept changes depending on the discipline, the date, and the national academic context. In its broadest sense, residential mobility can be defined as residence relocation regardless of the distance between the dwellings. A dwelling unit can also be broadly defined as any living quarter used to shelter a household, whether it is built in precarious materials or not, mobile or static. The concept of residential mobility encompasses under this definition internal and international migration, and changes of residence within the same urban area. However, the introduction of this concept in academic research has primarily responded to the need for measuring residence relocation within the same urban unit.

\section{Changes of focus on residential mobility and diversification of approaches}

Interest in the theme of residential mobility, and the angle from which the subject is treated, has evolved according to changes in societies and of the social demand. In the USA, at the end of the 1970s, most of the empirical and theoretical work was centered on interregional and interurban mobility: the concern was mainly to understand the mobility of labor. Research on intraurban residential mobility has mostly been developed since the 1970s. However, urban ecology works on the city of Chicago early started highlighting the relationship between intraurban residential mobility and urban change in a context of growth of the city by migration. In France, research on residential mobility was initially focused on migration due to the magnitude of the rural exodus in the middle of the twentieth century. Then, in the 1980s, the focus shifted to intraurban mobility due to the "urban crisis" and the highlighting of inequalities in access to urban resources. In Latin America, while the theme of internal migration is the subject of wide scientific interest, research on residential mobility within cities is rare and relatively new. In most of the national contexts, the focus shifted from the observation of migration in a context of rural exodus to intraurban residential mobility: as countries progress in demographic transition and urbanization, the relative weight of intraurban residential mobility is becoming more important than migration (Zelinsky 1971). In France, the idea of residential mobility started spreading widely in the social sciences in the 1990s. According to Jacques Brun (1993), the lexical shift from migration to residential mobility 
is not neutral and cannot merely be explained by the growing interest on intraurban mobility: it implicitly relates the geographical move and other forms of mobility - including social mobility and integrates a more comprehensive vision of mobility.

In parallel with the change of point of view on residential mobility, approaches have diversified from those establishing laws at a macroscopic level to those focused on individual behavior.

One type of approach focuses on factors of residential mobility at a macroscopic level. The first models to analyze interregional mobility were based on the macroeconomic theories of "pushpull": push factors impel people to leave their areas of origin and pull factors attract them to certain regions, according to the greater or lower presence of resources (jobs, housing, equipment). The Zipf model is a simplistic translation of this theory but more complex models have been developed. Moving to a microlevel of analysis, a second type of approach is based on microeconomic theories. In these theories, individuals make rational choices: as consumers they maximize utility - under the constraint of their incomes - and intentionally decide to relocate (De Jong and Gardner 1981). Despite the fact that these models take more and more factors into account (cost of relocation, duration of residence, household context, local social ties, etc.) and explain human behaviors in a simple way, they are criticized because of the assumptions that underlie them: for example, the fact that individuals are fully informed of the offer and of the consequences of their relocation, or that the aspirations are defined as common to the entire population. These approaches that give primacy to market forces and economic modeling are much more developed in the USA, whereas European researchers place more stress on the complexity of the mobility process, supposedly due to greater government intervention in the housing market (Strassman 2001).

A third type of approach can be called the "behavioral approach." This focuses on actual individual behaviors and on the decision-making process. These works show how residential choices can diverge from rational behaviors and be made under uncertainty. This type of research gathers studies from the relocation decision to the choice process. European and North American research highlights the role of the life cycle on the decision to move: relocation decisions are broadly related to the stages of the family constitution (leaving home, union, birth of children, child departures, etc.) and to the adaptation of housing to the new family situation. Other elements motivate individuals to change residence: the degradation of the residential environment, the desire for homeownership, looking for comfort, the affirmation of a new social status, or the choice of a new lifestyle. Anglo-Saxon works introduced the notion of residential stress to describe the mismatch between the household needs or preferences and the characteristics of the actual housing and neighborhood (Brown and Moore 1970). A household will relocate at a certain level of stress. The emergence in France in the late 1980s of the terms "residential strategies" and "residential choices," in a context of diversification of housing supply, highlights the flexibility that individuals and households have in the selection process. Residential choices result in the choice of a type of dwelling (house, apartment, size, comfort, architectural criteria), a tenure (ownership, rental), a location, and an urban context (on objective and subjective criteria). Households with different economic capital and social capital do not have the same flexibility: some have no or little choice and others have free choice and can express a particular logic of social, professional, or familial mobility (Authier, Bonvalet, and Lévy 2010).

The behavioral approach show the relations between life cycle and residential mobility and the role of long term experiences on the decision-making process. This led to the fourth type of approach: the life course approach. This approach focuses, through a lifetime perspective, on the link between different life domains of individuals (residential, family, professional) and on the 
interactions with other individuals' trajectories. It spread in the northern countries at the end of the 1980s but has much anteriority in Latin America and Africa.

In France, the introduction of the life course perspective in the discipline of demography expresses more generally the renewed interest in the individual actor in the social sciences. The shift in the study of residential mobility, from a transversal to a life course perspective, has been driven by numerous exchanges between disciplines and areas of empirical research. The transversal perspective, based on statistics on aggregated population at a given time, was the dominant approach in the mid-twentieth century in France. This was also the case in Anglo-Saxon literature until the pioneering work of Peter Rossi (1955), which centered the analysis of residential mobility at the household level. The statistics on aggregated populations described social facts but remained limited in interpreting phenomena by the ecological error - the error of interpreting the correlation between two aggregated measures at an individual level. Then the longitudinal approach was developed by introducing time into the analysis. This approach consists in the retrospective or prospective follow-up of homogeneous cohorts to study the occurrence of demographic processes, independently of each other. However, this approach does not encompass two overarching phenomena: the analysis of the heterogeneity of populations and the analysis of interdependencies between demographic phenomena. Putting away the hypothesis of independence of the various demographic phenomena, the life course approach highlights the interactions between the residential, familial, and professional trajectories. The focus on residential mobility thus altered in order to better understand individual behaviors, to study to which extent an event can influence the individual life course, and how distinct characteristics can push an individual to behave differently from another.

A survey set up in the 1960s in the city of Monterrey in Mexico, a pioneering study in Latin America, is a model in terms of observation of spatial mobility with a biographical approach. It collected the migratory, professional, educational, and familial trajectories of over 1,500 men living in the city. The biographical approach to residential mobility was then gradually developed through theoretical and methodological exchanges between disciplines. Biographies and life stories are tools widely used today. Now, data collection and analysis tools are broadly diversified and improved, contributing to a better understanding of the phenomenon of residential mobility. Abundant research focuses on the links between residential mobility and life cycle, and between residential mobility and occupational mobility.

\section{Achievements, difficulties, and new directions}

The measure of residential mobility is based on different sources: population registers, census data, and specific surveys. In the late 1990s, many studies of the factors of residential mobility showed recurrences of phenomena observed in various geographical contexts. Changes in the intensity of residential mobility during the life cycle are fairly well known: high at young ages, it falls back after 40 years and recovers, more or less, after retirement. The intensity and distance of residence relocations vary by income levels and socio-rofessional categories. Mobility is lower for owners and those who live in large homes. Finally, mobility is correlated to important life events: partnerships, divorce, births, changes in education, and work opportunities stimulate changes in residence. However, these events do not affect the distance of relocations in the same way. Changes in work are not decisive in residential mobility within the same city: they concern mainly long distance mobility. Several reasons are cited in the French literature but can be generalized to a large number of contexts: the modernization of intraurban transport means people move less for reasons linked to space, and, in a context of job instability, the dwelling has become the major social security. On the contrary, reasons for moving over short distances are more related to the adaptation of the dwelling to the size of the family. 
General trends are now fairly well known. Nevertheless, improvements of data collection and analysis tools revealed the complexity of transitions in the life cycle of individuals or of behaviors of certain groups. For example, works have focused on the study of young adults leaving the parental home, of elderly people retiring, or on the behaviors of ethnic groups. Most of the works show how complex or "fuzzy" certain transitions are (GRAB 2009) or highlight the diversity of life cycles. In many national contexts, growing family instability and job insecurity impact lifecycles and residential mobility. Studies in Western countries describe, for example, the phenomenon of return of young adults to the parental home after having an independent dwelling, because of economic difficulties or job loss. More recently, the conceptualization of the second demographic transition has encouraged new fields of research about solo living, recomposed families, and couples who do not share a dwelling (Coulter, van Ham, and Findlay 2015).

One of the contributions of the life course approach is to link lives through time and space and to take into account the interactions between individuals and structures. It is on these two points that innovations in collection and analysis of biographies have more recently been focused, but many challenges remain.

Despite the methodological innovations, measurement and interpretation of residential mobility phenomena remain difficult given the diversity of elements to take into consideration, the complexity of the facts, and the limitations imposed by the measure. First, residential mobility is often analyzed at the individual or household level. However, the use of the concept of household - that is to say the coresidents in a dwelling at a given time - is under discussion. This group is an entity that changes over time depending on people leaving, births, deaths, arrivals, and so on. Also, the residential stability of a household may, as shown in some works in West Africa, hide a high residential mobility of individuals attached to it. Conversely, studies on residential mobility have shown that the mobility of individuals is rarely isolated and must be analyzed with respect to their collective or family unit. In Africa, the detection of circulations of people through all the dwellings of the extended family, described under the concept of the family residential system, revealed the multilocal character of family strategies. The concept of residential system was then used more broadly by considering all the places of residence of individuals and their families. In Latin America, the multiresidence of individuals and families was taken into account very early in surveys in Mexico, Ecuador, and Colombia. The complexity of these flows encounter measurement problems, particularly because of the shortness of the time scales on which these movements are held. In response to these challenges, surveys in India, Latin America, and West Africa have gradually introduced innovations in the collection of spatial mobility, feeding one another or inspired from other experiments, driven by the will to take into consideration the movements of individuals between different dwellings or different places of life, and to include people in their relation networks. In France, the survey Biographie et Entourage conducted by the French Institute for Demographic Research (INED) in 2001 is one of the most thorough biographical survey in aiming at liking lifes. Through the development of the concept of "entourage," the survey featured a retrospective collection of information on family members, members of the different households to which the individual belonged, and key individuals in the life of the respondent. However, this approach faces practical difficulties: the restitution of life courses by a third person endangers the quality of the information and the amount of information needed leads to large time requirements.

In addition, the life course approach guides us to analyze the interaction between residential mobility and wider structures, and to study how individual behaviors contribute to the production or the reproduction of sociospatial structures (Coulter, van Ham, and Findlay 2015).

The introduction of the notion of residential trajectory invites a renewed interest in the study of the relationships between social mobility and spatial mobility. In demography, this 
relationship is usually studied according to dwelling characteristics (tenure, comfort). Moving from a rental unit to homeownership is often associated with the idea of an upward trajectory and the opposite as a downward trajectory. The qualitative work of sociologists also shows that, for households, the choice of the place of residence corresponds to a choice of a lifestyle, indicating more or less consciously their social position. Then, characterizing the successive places of residence of an individual describes their social trajectory from residential choices - made according to the social labeling of spaces and habitat types - and considers their social position according to the resources offered by proximity - social, environmental, equipment (Lévy 2003). Thus, the residential trajectories, in an economically and socially selective space, are partly a reflection of social trajectories. This angle of analysis, which has been the subject of a significant literature on "spatial assimilation" in the case of ethnic minorities in the USA, has been more scarcely developed from a wider sociodemographic perspective.

In return individuals socially requalify the spaces in which they settle. Urban change results, then, from the interaction of residential trajectories and spatial dynamics. For example, some research has highlighted the interactions between residential mobility and the dynamics of the housing stock through the study of household succession mechanisms (Bourne 1981). This method aims at following the mobility of a household, usually in a new home - but also by the death or the departure of the agglomeration, the release chain and reallocation of housing that it entails: a household moving to a new home releases its dwelling which will be occupied by another household which leaves its own, and so forth. This chain of released dwellings initiated by the move of a household - called a vacancy chain - stops when a property is destroyed or when children leave home - no housing release in this case. Following vacancy chains, which evolve in the inverse way to households' residential mobility, is an investigation method initiated in the 1950s. Empirical work in major cities in Canada, England, and France showed that vacancy chains are relatively compartmentalized channels which generally reproduce social hierarchies. Households of different social levels can see their living conditions improve during their residential trajectory but in separate channels. The channels are influenced by the local context and, in return, the mobilities associated with the vacancy chains alter the context for future mobility chains. These mobility channels thus maintain social divisions of space but can also evolve over the long term through their impacts on the local contexts and the housing supply. The release and reassignment of housing, which constitutes the pulse of the process, depends not only on demographic phenomena (children leaving home, deaths, arrivals, and departures from the urban area), but also on housing production and transformation (construction, demolition, renovation, or modification of dwellings). These illustrations show how the spatial context influences mobility and in return how residential mobility impacts the local context.

The spatial contextualization of the residential trajectory depends on the accurate measurement of places during data collection. In connection with changing issues - from the measure of migrations to the study of residential behaviors - the reduction of the geographical scope of biographical surveys favored a more accurate collection of locations, allowing the characterization of successive places of the trajectories through secondary sources. It remains necessary to consider on the one hand context evolution, in order not to make the mistake of retrospectively characterizing places according to their current situation, and, on the other hand, that places are changing even when individuals are immobile. One difficulty remains in choosing the levels of context that characterize or influence the trajectories. In addition, studying interactions between intraurban dynamics and residential trajectories requires establishing a particularly complex observation system. 


\section{References}

Authier, Jean-Yves, Catherine Bonvalet, and Jean-Pierre Lévy, eds. 2010. Elire domicile. La construction sociale des choix résidentiels. Lyon: Presses Universitaires de Lyon.

Bourne, Larry S. 1981. The Geography of Housing. London: V. H. Winston.

Brown, Lawrence A., and Eric G. Moore. 1970. "The Intra-Urban Migration Process: A Perspective." Geografiska Annaler, Series B, Human Geography, 52(1): 1-13.

Brun, Jacques. 1993. "La mobilité résidentielle et les sciences sociales." Les Annales de la recherche urbaine, 59-60: 2-13.

Coulter, Rory, Maarten Van Ham, and Allan M. Findlay. 2016. "Re-Thinking Residential Mobility Linking Lives through Time and Space." Progress in Human Geography, 40(3): 1-23.

GRAB. 2009. Furay states and complex trajectories. Observation, modelization and interpretation of life histories. Paris: Éditions de l'INED.

De Jong, Gordon F., and Robert W. Gardner, eds. 1981. Migration Decision Making. New York, NY: Pergamon.

Lévy, Jean-Pierre. 2003. "Population patterns and household trajectories milieu: The example of the Seine-Saint-Denis." Population (English), 58(3): 323-358.

Rossi, Peter Henry. 1955. Why Families Move: A Study in the Social Psychology of Urban Residential Mobility. Glencoe, IL: Free Press.

Strassmann, W. Paul. 2001. "Residential Mobility: Contrasting Approaches in Europe and the United States." Housing Studies, 16(1): 7-20.

Zelinski, Wilbur. 1970. "The Hypothesis of the Mobility Transition.» Geographical Review, 61(2): 219-249.

\section{Further reading}

Bonvalet, Catherine, and Jacques Brun. 2002. "Etat des lieux des recherches sur la mobilité résidentielle en France." In L'accès à la ville: les mobilités spatiales en questions, edited by JeanPierre Lévy and Françoise Dureau, 15-64. Paris: L’Harmattan.

Clark, William A. V., and Frans M. Dieleman. 1996. Households and Housing: Choice and Outcomes in the Housing Market. New Brunswick, NJ: Center for Urban Policy Research.

Courgeau, Daniel. 2002. "Evolution ou révolutions dans la pensée démographique?" Mathématiques et Sciences bumaines, 160: 49-76.

Dureau, Françoise. 2002. "Les systèmes résidentiels: concepts et applications." In L'accès à la ville. Les mobilités spatiales en questions, edited by Jean-Pierre Lévy and Françoise Dureau, 355-382. Paris: L'Harmattan.

Dureau, Françoise, Matthieu Giroud and Christophe Imbert. 2015. "Event history approach to life spaces in French speaking research". In Researching the lifecourse : critical reflections from the social science, edited by Irene Hardill ans Nancy Worth, 215-230. Bristol: Policy Press.

Quigley, John M., and Daniel H. Weinberg. 1977. "Intra-Urban Residential Mobility: A Review and Synthesis." International Regional Science Review, 2(1): 41-66. 